Published on Reviews in History (https://reviews.history.ac.uk)

\title{
Commemoration and Oblivion in Royalist Print Culture, 1658-1667
}

Review Number: 2182

Publish date: Thursday, 26 October, 2017

Author: Erin Peters

ISBN: 9783319504742

Date of Publication: 2017

Price: $£ 66.99$

Pages: 196pp.

Publisher: Palgrave

Publisher url: https://www.palgrave.com/de/book/9783319504742

Place of Publication: London

Reviewer: Imogen Peck

Erin Peters, Commemoration and Oblivion in Royalist Print Culture, 1658-1667 (Palgrave Macmillan, 2017), 184 pp., ISBN: 978-3-319-50474-2, £52.99

In the spring of 1660, Charles Stuart set sail for England after almost ten years in exile on the continent. On 25 May he landed at Dover, where according to the diarist Samuel Pepys, he was greeted with 'all imaginable love and respect', the 'shouting and joy' expressed by the crowds 'past imagination'.(1) His restoration to the throne marked the end of the 11 years of republican rule that had followed his father's execution on 30 January 1649. However, in spite of the apparently jubilant reception of his subjects, upon his return Charles was confronted with a difficult political situation: on the one hand, the King owed his restoration to a broad coalition of support - including members of the army, Presbyterians, and moderate revolutionaries - while on the other hand, many royalists who had fought for Charles I and suffered during the years of Interregnum anticipated that the tables would now turn, and they would be able to reap revenge on their erstwhile enemies. The monarchy may have been restored, but all was not as it had been before, and the new regime was faced with a tricky balancing act between the competing impulses of retribution and reconciliation, commemoration and oblivion, remembering and forgetting.

In Commemoration and Oblivion in Royalist Print Culture, Erin Peters seeks to uncover the ways in which the Restoration regime and its supporters navigated this tension, paying particular attention to their various attempts to use printed material to prescribe which aspects of the turbulent recent past should be remembered, and how, and which were best consigned to oblivion.

In common with other books dedicated to the memory of Britain's domestic conflicts, most notably Matthew Neufeld's 2013 study The Civil Wars after 1660 - similarly, an exploration of the restored monarchy's efforts to control the public memory of the recent past - Peters is 'less concerned with what individuals in this period remembered or forgot about the past as with the ruling regime's [...] use of the past for their present purposes' (p. 2).(2) However, as Peters makes clear at the outset, her study differs from Neufeld's not only in its temporal scope, but in its choice of source material. For though Peters' focus is on print culture, she is concerned with a particular form of printed material - 'widely distributed, inexpensive pamphlets and broadsides' (p. 1), or popular print. As a consequence, some of the sources that one may 
expect in to find in a book concerned with the study of memory, including histories, memoirs and commemorative sermons, are conspicuous by their absence. Yet as Peters notes, in recent years these forms of memory have received significant scholarly attention, and the result of her decision is a study that makes a welcome attempt to expand the field of early modern memory studies beyond its traditional focus on a rather narrow source body. $\underline{(3)}$

The book's central claim is that Restoration England was characterised by a simultaneously commemorative and oblivial culture, and that both selective remembering and forgetting were applied to the collective memory of the recent past when deemed appropriate either by the Restoration regime or its supporters. Thus, in spite of the strictures imposed by the 1660 Act of Indemnity, Pardon and Oblivion, which stated that any person 'in any way tending to revive the memory of the late difference' was to be punished accordingly, recollection was as much a part of Restoration culture as forgetting.(4) This claim is vividly illustrated in the chapters that follow, each of which traces a different aspect of the royalist efforts to remember - and forget the Civil Wars and Interregnum.

Following an initial chapter which establishes the aims and parameters of the study, the second chapter offers an analysis of the regime's preferred version of the recent past, in which managing a careful balance between what was commemorated and what was forgotten played a vital strategic role. Thus, while the commencement of Charles II's reign was backdated to 1649, effectively drawing a veil over the events of the previous decade, printed material nevertheless encouraged people to remember those aspects of republican rule that might buttress support for the new regime, not least its various alleged failings. As one anonymous pamphlet reminded its readers, the governments of the previous 11 years had not produced 'any other Effect than Misery, and Oppression, a Decay of Trade, Endless Taxes and Excise [...] as no former age can Parallel' (p. 42). The Act of Oblivion offered a pardon to most of the Parliament's former supporters and sought to suppress discussion of the recent divisions, but vengeance was meted out through the public execution of 13 surviving regicides, and the dismemberment of those who, like Cromwell, had not lived to see their just desserts served. Similarly, while many printed texts sought to establish who was culpable for the wars and the regicide, these texts tended to restrict blame to a few key figures, offering readers a way of remembering the past which absolved the vast majority of English men and women from responsibility. The result of these diverse contradictory efforts, Peters argues, was to blur divisions between past and present, remembering and forgetting, creating a commemorative landscape of marked complexity.

Throughout the chapter, Peters deploys concepts that have been developed by scholars in the field of modern memory studies, and particularly Paul Connerton's typology of the seven different forms of forgetting. (5) While this decision might initially appear to run the risk of adding unnecessary obfuscatory jargon, it actually proves to be one of the book's major strengths, enabling Peters to analyse a large quantity of disparate printed material with clarity and to make subtle distinctions between the content and purpose of different texts. Moreover, the applicability of these categories to an early modern context suggests a degree of commonality between the strategies deployed by the Restoration regime and those of other, more modern post-war states, opening up a line of enquiry that might be fruitfully be pursued further.

In the third chapter, Peters shifts her attention to one particular form of Restoration narrative - myths and legends about significant individuals - and explores how these stories helped to reinvent and revalidate monarchical rule. The discussion is framed around the representation of three key figures: Charles I, Charles II and Oliver Cromwell. Perhaps inevitably, given the sheer quantity of existing scholarship on the cult of Charles the martyr, the section on Charles I re-treads largely familiar ground.(6) The discussion of the representation of Charles II, however, is illuminating, especially as there are comparatively few historical studies that focus on the image and representation of the restored Stuart monarchy in popular print.(7) The early Restoration years saw a surge of publications intent on presenting a specific image of Charles II to the people, and Peters demonstrates that, in so doing, authors often chose to build on myths and legends already familiar in English folk culture. For example, the story of Charles II flight from England in 1651 disguised as a farmer's son was explicitly likened to the tale of King Alfred, who allegedly travelled the country dressed as a peasant in order to assess his subject's welfare. Peters argues that layering of tales about the 
new King with stories about past monarchs served to lessen the foreignness of Charles II to his subjects, transforming an unknown and potentially threatening quantity into something familiar and comforting, while also making explicit his right to rule. By contrast, the late Lord Protector was generally represented as the very embodiment of evil and was often held single-handedly responsible for the bloodshed of the previous decades, an allocation of blame that neatly side stepped the rather inconvenient truth that a large portion of the nation had fought for the Parliamentarian cause.

In the discussion of Cromwellian ghost dialogues in this chapter, Peters notes that this genre of text declined in popularity in the years after 1660, and speculates that this may reflect the fact that ghost narratives did not necessarily represent the views of the regime itself and were not officially commissioned (pp. 95-6). This raises the intriguing question of how far official, government commissioned printed material differed from those texts that were produced by unofficial supporters of the Restoration regime. Peters briefly returns to this theme later in the book, when she notes that attempts by the Historiographer Royal, James Howell, to link the early Stuart past to the restoration present had much in common with the nostalgic narratives circulating in popular print (p. 125). Nevertheless, in the absence of an in-depth comparison of popular print and the lengthy, formally commissioned texts and histories produced during the later 17th century, a conclusive answer to this question remains tantalisingly out of reach.

In the final chapter, Peters turns to what she considers to be 'the most distinctive strands of cultural memory evident in early Restoration print sources' (p. 107): expressions of collective trauma and nostalgia. Her discussion of 'collective trauma' here is wide-ranging, touching on subjects as broad and apparently distinct as the difficulties faced by authors attempting to relate the unrelatable, the potentially therapeutic purpose of war narratives and the creation of providential accounts of the recent past. The central argument here is that the contradiction between remembering and forgetting stemmed in part from the 'significant levels of cultural traumatisation' experienced by Restoration society (p. 110). How compelling a reader may find this claim perhaps depends on whether they are willing to accept the notion - by no means unique to Peters' work - that trauma, more commonly understood as an individual psychological condition, can be experienced on a collective level.(8) For this reviewer, this was the only point in the text where the use of term borrowed from modern memory studies obscured more than it clarified, and though there are some interesting points here - not least the suggestion that the re-publication of Civil War narratives from the 1640 s during the 1660s points to a rise in attempts to 'work through' the events of the past (p. 114) - I am not entirely convinced that they are best understood under the somewhat opaque umbrella of collective trauma.

The discussion of nostalgia in this chapter, however, is original and compelling. Peters convincingly shows that, faced with yet another political transformation, royalist authors deliberately deployed an idealised version of the pre-Civil War past in order to garner support for the Restoration state in the present. As the author and playwright Thomas Forde put it, the years of Charles I's reign had been the 'pitch of felicity', a time when, unmolested by the oppressive taxes favoured by the Interregnum governments, 'Everyman sate under his owne Vine and Fig-tree, eating the fruit of his own labours' (p.131). The halcyon days of the early 1600 's thus established, authors were able to present the new restoration state as a straightforward continuity of this rosy past. Once again, calls to remember went hand in hand with a certain degree of necessary forgetfulness.

If I have a reservation about the project, it is that the material from the years of 1658 and 1659 might have benefitted from being read alongside the numerous texts published by authors of other political persuasions during this period. For in contrast to material published after the Restoration (and especially after the Act for the regulation of print and printing presses in 1662), print produced during the latter years of the republics was operating in a climate in which there were multifarious, competing accounts of the recent past in circulation. In 1658 and 1659, a return of the monarchy was by no means the only alternative political system available, and writers of a range of political stripes, from Commonswealthmen to defenders of the Protectorate, attempted to marshal the memory of the recent past to buttress their preferred vision for the future. Peters' decision to focus solely on royalist print means there is little consideration of the alternative 
narratives that royalist authors writing in these years may have been responding to, or of the fact that prior to 1660 the various governments and their supporters had sought to establish a distinct, republican

commemorative culture, one that influenced both the nature of print produced in the 1650 s and the narratives that emerged after 1660.(9) In this respect, the book reinforces my view that there might be much to be gained from taking a more integrated approach to the political and commemorative culture of the period, which still tends to bifurcate into pre- and post- Restoration scholarship.

But this is only a minor quibble with what is an original, carefully researched and highly readable book, one that will be of interest not only to those interested in early modern memory, but to scholars of Restoration culture and early modern print more generally. The book's particular strengths are its innovative use of concepts from the broader memory studies project to shed fresh light on forms of remembering (and forgetting) in the past, the careful analysis of wide range of printed sources, and the sensitive treatment of royalism, which, in line with recent work by Jason McElligott, David Smith and Barry Robertson, emerges from this study as a highly complex and varied coalition. $\underline{(10)}$

In the afterword, Peters reiterates that she has not attempted to study the reception of these texts, their impact on their readers, or the ways in which the men and women of Restoration England actually did recall the events of the recent past, and she rightly flags the potential for further work in these areas (p. 144). Other potentially fruitful lines of enquiry may include the ways the Civil Wars and Interregnum were remembered in the rest of the British Isles (Peters' focus on print culture means that her account is necessarily rather Anglo-centric), the development of popular accounts of the recent past after 1667, and the similarities (and differences) between the Restoration experience and those of other post-war states. It is a testament to the lively state of the field, and the originality of the contribution Commemoration and Oblivion offers, that it succeeds in raising as many questions as it answers.

\section{Notes}

1. The Diary of Samuel Pepys, ed. Robert Latham and William Matthews (London, 1995), vol. 1, p. 158. Back to (1)

2. Matthew Neufeld, The Civil Wars after 1660: Public Remembering in Late Stuart England (Woodbridge, 2013). For studies that do focus on individual memories of the Civil Wars after 1660 see Andrew Hopper, 'The Farnley Wood Plot and the Memory of the Civil Wars in Yorkshire', The Historical Journal, 45 (2000), 281-303; Mark Stoyle, 'Memories of the Maimed: the Testimony of Charles I's Former Soldiers, 1660-1730', History, 88 (2003), 204-26.Back to (2)

3. For work on histories of the Civil Wars see Blair Worden, Roundhead Reputations: The English Civil War and the Passions of Posterity (London, 2001); David Cressy, 'Remembrancers of the Revolution: Histories and Historiographies of the 1640s', in The Uses of History in Early Modern England, ed. Paulina Kewes (Berkeley, CA, 2006), pp. 253-64; Gary Rivett, Make Use of Both Things Present and Past: Thomas May's Histories of Parliament, Printed Public Discourse and the Politics of the Recent Past, 1640-1650 (Unpublished PhD thesis, University of Sheffield, 2010). For memoirs see Andrew Hopper, 'Black Tom': Sir Thomas Fairfax and the English Revolution (Manchester, 2007); Jack Binns, Sir Hugh Cholmley of Whitby 1600-1657: Ancestry, Life and Legacy (Pickering, 2008). For 30 January and 29 May commemorative sermons, see Neufeld, The Civil Wars After 1660, pp. 203-41. Back to (3)

4. 'Charles II, 1660: An Act of Free and Generall Pardon Indempnity and Oblivion' in Statutes of the Realm: Volume 5, 1628-80, ed. John Raithby (Great Britain Record Commission, 1819), pp. 226-34. Back to (4)

5. Paul Connerton, 'Seven Types of Forgetting', Memory Studies, 1,1 (2008), 59-71.Back to (5)

6. See, for example, The Royal Image: Representations of Charles I, ed. Thomas Corns (Cambridge, 1999); Kevin Sharpe, 'So hard a text?’ Images of Charles I, 1612-1700', The Historical Journal, 43, 2 (2000), 383-405; Andrew Lacey, The Cult of King Charles the Martyr (Cambridge, 2012).Back to $\underline{(6)}$

7. Kevin Sharpe, Rebranding Rule: The Restoration and the Revolution Monarchy, 1660-1714 (New 
Haven, CT, 2013), p. xvi.Back to (7)

8. See Jeffrey Alexander, 'Toward a Theory of Cultural Trauma', in Cultural Trauma and Collective Identity, ed. Jeffrey Alexander, Vered Vinitzky and Daniel Levy (Berkeley, CA, 2004), pp. 1-32.Back $\underline{\text { to }(8)}$

9. I am currently working on a $\mathrm{PhD}$ thesis that explores memories of the Civil Wars and the commemorative culture of the British republics between the execution of Charles I and the Restoration of the monarchy.Back to (9)

10. Jason McElligott and David Smith, 'Introduction: rethinking Royalists and Royalism during the Interregnum', in Royalists and Royalism during the Interregnum, ed. Jason McElligott and David Smith (Manchester, 2010), pp. 8-9; Barry Robertson, Royalists at War in Scotland and Ireland, 1638-1650 (Farnham, 2014), pp. 11-22. Back to (10)

Source URL:https://reviews.history.ac.uk/review/2182

\section{Links}

[1] https://reviews.history.ac.uk/item/274271 